\title{
Governance and Land Management Fires Understanding Objects of Governance as Expressing an Ethics of Dissensus
}

\author{
Helen Verran \\ Professorial Research Fellow \\ Northern Institute \\ Charles Darwin University \\ helen.verran@cdu.edu.au
}

Keywords: Objects of governance, Aboriginal, firing, land management, ethics, environmental science, dissensus

Having worked in science studies for many years, objects of knowledge are my usual focus of analysis. In particular in the past I have puzzled about how the objects that scientists know, and objects that practitioners of Aboriginal Australian knowledge traditions know, might be connected and separated. One example of that analytic work involved analysing the objects of knowledge involved as scientists and Aboriginal landowners engaged with each other around land management firing (Verran, 2002a).

In 2014 I find that the character of the entity that is my focus of analysis must change. Epistemic practices as such, are no longer of much interest to those who fund research in Australia. Nowadays it is objects of governance that are of interest. Of course objects of governance come to life as knowable in knowledge practices, but it is not their capacity to constitute enough certainty about the world known that matters nowadays. It is their role in allowing transparent organisational accountability that now matters. And that shift is accompanied by changed institutional arrangements. Research associated with services provision is now largely the order of the day in Australian universities. Thus it is that, near the end of my career, I find myself working in 'GroundUP,' a research group and a services provider located in a policy research unit in Charles Darwin University (see Charles Darwin University's webpage www. cdu.edu.au/centres/groundup/). No longer a field worker, I am a story-teller who worries at coming up with some useful naming's of what we are doing in our ground-up policy research and services delivery projects.

It is in the context of that groping around for useful accounts of what we do as social scientists nowadays, that here I return to two papers I wrote around the turn of the century focusing on Yolnu land managers working with environmental scientists on the topic of land management fire. The puzzle I attend to in my paper is this: in working in contemporary Aboriginal communities I have many times been part of episodes where disparate and multiple objects of knowledge are somehow in the event of governance, effected as a singular object of governance. This occurs regularly even in collectives where disparate knowledge traditions and epistemic standards are actively in play. I propose that thinking of objects of governance as events, as expressions of a collective going-on together in a particular here and now, offers a means to consider the ethics and politics of a particular going-on doing difference together. This can help reveal what might be involved in that puzzling process of singularising a governance object-a process that necessarily involves multiple objects of knowledge. Here such singular governance objects are understood as an expression of an ethics of dissensus, 
operationalised as a politics of dissensus, where we all must actively assent here and now to go on together, and recognise that such assent might be withdrawn. I propose dissensus as an ethics and politics of good faith and bad will.

'Dissensus' is a neologism from the Latin dissensio, 'disagreement, struggle.' Note that it is not dissention that I am promoting here for dissention implies recognition of a consensus which can be dissented from. I imagine dissensus as everted consensus-consensus pulled inside out, so the inside agreements that get hidden and lost in consensus are on show. One of the aspects of the term I value is its embedding of the root term sensus, with its implications of 'making sense,' and of involving the senses. We are dealing with embodied and embedded knowing subjects here. For me thinking about ethics starts with ethos, a Greek term referring to 'the character of the guiding beliefs or ideals of a group.' I prefer the notion of commitments shared by a group and hence I take ethics as the commitments of a group doing difference in going on together. A group of Aboriginal landowners and environmental scientists engaging over land management firing is just such a group.

'Doing difference together.' It has a nice, touchy-feely ring to it but enacting such an ethic is challenging, not least because it presupposes a new political ontology. An ethic of doing difference together involves participants in acting out the aporia of collectivity with its obligations to present, the here and now and its purposes, but equally obligations to myriad other times and places, which can clash with the commitment to the here and now. It can be epistemic and morally alarming to find that such commitments to other times and places are deeply embedded in working ones working categories and concepts. This is an aporia since it is experienced as an impasse, a disconcertment. In an ethics of dissensus, this aporia is managed with good faith and bad will.

In working in the research group and a services provider known as GroundUP, I find myself participating in the collective enactment of the phenomenon of good governance in Aboriginal communities being seen as "a public problem" (Smith, Bauman \& Quiggin, 2014, p.15). This status of good governance in Aboriginal communities as a public problem still comes as something of a surprise. In the 1980s and 1990s along with many others (some of whom are my co-researchers in GroundUP), I was deeply involved with governance in Yolnu Aboriginal communities. There was no public problem then, or if there was, it was a problem of Yolnu governance being too strong, too explicit, and too forthright. Yolnu Elders involved in governance in the Yirrkala School Council and the Yirrkala School Action Group for example, regularly took it upon themselves to instruct government officers on proper procedures of governance in Yolnu curriculum development and Yolnu pedagogy and Yolnu institutions.

However that era ended rather suddenly in the mid-1990s when devolved Aboriginal governance of state funded organisations like schools, was firmly shut down, associated with the institutionalising of a normalised and standardised curriculum in Aboriginal schools. Back then, the striking about-face on school governance by government was associated with the early stages of the rise of neoliberalisms in Australia. Now, seemingly paradoxically, under the very ideology that shut down the Yolnu Aboriginal governance practices we participated in, some of us are retained by the state to attend to what it sees as an absence or a deficit in good governance in organisation in Aboriginal communities. The reasons for that turn around are interesting, involving as they do a re-configuring of state and its people-places, and of their relations. I will not be considering that set of issues here, nevertheless it frames the reconsideration I make in this short paper.

In beginning this reconsideration of episodes I participated in nearly twenty years ago, this time focusing more on governance practices and less on knowledge practices, I point out that in delivering services to do the state's bidding in meeting our contractual obligations, 
GroundUP does not purport to know what governance is in any specific sense. In the collective life of several contemporary Aboriginal communities we find governance as sets of practices emerging as a named public problem; this becoming of governance as problematic emerges in all sorts of contexts. Our method is to attend to each context as a particular, rather than as calling for a general set of skills or techniques to find 'a solution'. Here I implicitly defend that seemingly unprofessional stance, refusing definition of the very process we have been retained to 'improve' in our delivery of services, by suggesting that an open ended focus on objects of governance is ethical. The work of GroundUP is political in attempting to interrupt, to slow down the rush toward formation of too hasty and unsustainable a consensus. Going on together will occur, Aboriginal communities do assent to be governed as a constituent part of the Australian state, but past practices of imposing brittle ad hoc agreements reached under pressure of a government timetable, have a long history of failure in Australia's Aboriginal communities.

In this paper I develop a particular understanding of objects of governance as events, as configured happenings of a present here and now. This is an idea we started to develop in our writers' workshop, in learning from Foucault's notion of governmentality (2007), and from Serres' writing (1995). But I go further by proposing that as configured happening of the present, objects of governance should be read as expressing an ethics of dissensus and as emergent in a politics of dissensus which slows down. Unlike consensus, which requires good will but often entails bad faith, a politics of dissensus requires good faith which necessarily goes along with a judicious engagement in bad will. An ethics of dissensus, expressing a metaphysical commitment to emergence of worlds all of apiece in here and now's, resists established power relations and transforms the negative moment of resistance into the creation of new modes of beings. The emphasis on discontinuous becoming and emergence that this analytic enables, shifts the ethical problematic from the concern with universal (or relativised) norms enacted as consensus, to tasks of transforming here and now's beyond present limits. Since any such transformation occurs within the materiality of a particular here and now, an ethics of dissensus contests giveness in objects of governance. A politics of dissensus, like any politics is concerned with 'What particular choices present in this here and now?', 'What is at stake in those choices?' 'How might those choices be made?' But unlike the politics of consensus where those questions are ruled out of play after a consensus has been agreed, in dissensus those questions continue to remain active. Assenting here and now in going on together doing this, is limited and contingent. There is shared recognition that what we do together is subject to a continuing and active deferral of the always hovering possibility of withdrawing assent, of stopping things in their tracks.

\section{My Past Experience of Engagement through Land Management Firing}

In the mid-1990s I found myself working with Mandawuy Yunupingu and others in establishing the Yothu Yindi Foundation (YYF) as a non-governmental organisation offering cultural services to both Yolnu and Balanda organisations. In 1995 our still newly established organisation teamed up with the Yolnu environmental NGO Dhimurru, already well known in the then rapidly changing institutional landscape of Yolnu organisations. Across three years (1995-97), Dhimurru was awarded grants to work with YYF by the NT government, to run workshops in which Yolnu Aboriginal landowners would instruct invited environmental scientists working in NT institutions (industry, government, and civil). The aim was to demonstrate Yolnu methods of using fire as a land management tool for those involved in scientific environmental management, for by the mid-1990s it was recognised that the biodiversity index of Aboriginal managed lands was far higher than scientifically managed lands. 
I attended two of these workshops in Dhalinbuy (1995) and Wathawuy (1996) alongside Mandawuy as a representative of YYF. My task (being a philosopher of science) was to do cultural brokerage work during the workshops in discussing the philosophical difficulties of translating knowledge based practices like land management firings. With good reason as it turned out, we worried that scientists would be impatient with what they saw as mere culture and belief being passed off as knowledge by Aboriginal land-owners. Here I reconsider some of the empirical material displayed in analysing the knowledge practices displayed in those workshops.

The focus of my reconsideration of these episodes and the analysis I developed from the experience, brings issues of governance to the fore. The papers published over ten years ago proposed worrk (Yolnu Aboriginal firing work) and prescribed burns as disparate objects of knowledge. I argued that in the workshops we could see that during the shared experience of firing a tract of land together, both scientists and Aboriginal knowers worked assiduously to generate the fire as epistemic objects that met the metaphysical requirements of being precisely knowable in their quite disparate knowledge traditions. Both Aboriginal landowners and environmental scientists, each in their own way, attempted to meet the epistemic obligations they felt towards fires as objects of knowledge. In the process they each seemed to experience considerable irritation at the 'inappropriate practices' of 'the other.' My claim was, and is, that in generating that mutual irritation the workshops showed themselves as successful.

Making this more explicit still, in a third and more recent paper focusing on a small incident that occurred in the opening stages of the Wathawuy workshop, I have suggested that my work as a cultural broker in the mid-1990s would have been more successful if I had found a viable way to maintain and even exaggerate that mutual irritation in developing a technique that worked as a form of epistemic astringent. In opposing well-meant impulses of good will, designed to cultivate consensus, on the part of both scientists and Yolnu land management practitioners (but never on the part of the Yolnu knowledge authorities who were quite uncompromising in their presentations), a few years ago I saw that what was needed was a proposal of acceptable ways for participants to enact dissensus publically and as a group, rather than as separately and rather covertly, as happened during the workshops' evaluation phase (Verran, 2013, pp.141-161). I now develop that argument to propose that explicit dissensus articulated as part of the here and now of the workshop, would have revealed the fires that eventuated as singular objects of governance, as events of going on together explicitly doing difference.

In my paper analysing the Wathwuy workshop as an epistemic episode embedding a postcolonial moment, I proposed it as simultaneously a particular worrk, one that is highly specific to both its timing and its area, and an instantiation of the general scientific category of prescribed burn. Below I present short texts exerted from larger texts assembled by the disparate epistemic practitioner groups. In my original paper these were treated as mere descriptions of the organisation; as accounts of what organisational work was entailed in worrk and prescribed burn. I now propose these texts as explanations of the moral relations work associated with the known fires.

When viewed as explanations of the moral relations involved in firing, as we would expect they are very different. Unsurprisingly firings turn out to be where 'our values', the norms of our society, who is inside and what is outside, are (re)negotiated, along with various other matters. Juxtaposing these accounts of the collective moral work involved in firing as understood by the different expert groups involved, reveals that the event of a firing effects a moral distribution both in modern scientific land management and in Yolnu land management. Scientific firing and Yolnu firing by expert groups each judge that moral relations are involved in firing, although 
what these relations are, varies. And equally, they conceive distribution in radically distinct ways. Juxtaposing these, as outsiders, we can only offer respect at the considerable political accomplishment of these workshops. The fact that these two groups of experts can go on together is no small achievement.

\section{Exhibit one: Wathawuy Worrk}

The land around this area belongs to three Dhuwa tribes: Galpu, Ngaymil and Djapu. All other Dhuwa groups only associate with the land through the history of Wukun - the cloud which is an origin of meanings for Yolngu. The spear (the cloud) is called Djäta, Milpiriny Larrpan.

The bay is called Djarraran, Manybarrmi, Gawinymi; sea in the colour of the rainbow. Here Dhuwa people sing the Ngamal the stingray and Bukumilan, the shark. The water is called Dhara'mälami. (The work) to reproduce the water and the sea in the bay is known as Mälami dhara'mi.

History tells us that Wukun stood at Wurrumba Galkirrwalkirr and pointed to Watharrandji. Then pointed towards Wotja and then towards the east to Yirrkarpa Djawulpawuy. Then it pointed towards the north to Wayirriwayirri Rarrakala. Then it broke up into small clouds, into the many Dhuwa tribes of Northeast Arnhemland.

We were told that people must respect the land and celebrate it and the ancestors who made it, in taking from the land what was needed and in distributing it in the proper ways. That was what all young people must learn. Making sure that the respect for the land was given back through dancing, singing and holding proper ceremonies.

And when this land burns, the smoke rises up across the day. And helps make that cloud Wukun. By the end of today we will see the cloud forming and setting off on its journey. So here we are working together in ways we have always done, and remaking the connections between Wathawuy and other Dhuwa places.

(Ngaymil Clan leader, translated by Mandawuy Yunupingu)

\section{Exhibit two: Prescribed Burn}

1. Initial planning. A broad plan is devised to reconcile protection of property with conservation needs and cultural heritage. This is done well in advance. Local communities and stakeholders are involved.

2. Preparation. Boundaries are prepared for the fire (fire trails, walking tracks, streams that will hold a fire line, etc.). Where these do not exist, 'rake-hoe' or hand tools are used to construct fire control lines. Fire trails may be upgraded. Boundaries are made more secure. For instance, fuel is cleared from around trees lest they catch fire and fall across the control line or drop burning embers across it. This work can be done some time before the burn. Ecologically sensitive areas may need to be identified and excluded by control lines. Fuel loads are assessed in detail for the entire burn.

3. Detailed operational planning. The fire's likely behaviour is modeled using computer simulations for that precise area ('the burning block') ... The managers know how they want the fire to behave, and from this they can deduce the window of weather conditions they will need. 
4. $\quad$ Setting a date. A band of possible dates is set for which it is predicted that suitable weather conditions will prevail. Usually such burns involve local fire brigades and neighbours, so everyone's timetable has to be considered.

5. Division of tasks. Typically, the operation is divided up - different groups have different duties and work in different sectors. One team may be dropping incendiaries from a helicopter while a ground crew (supported by a fire-tanker) sets fires elsewhere at precise points along the established control lines. The operation may also be sub-divided into time stages. The organisation that initiates the overall plan will probably be responsible for mopping up after the burn-off for the following days until it is declared safe.

6. The lighting-up plan. This involves deciding exactly where and in what order fires will be lit. The correct sequence matters; it determines what burns first, and in what direction fires can move. Fires can be volatile when moving up steep slopes so these areas are often lit from above. The fires then burn downwards to control lines (where possible) at the base of hills, or into pre-burnt areas. Humidity also affects the behaviour of fires, so 'time-of-day' lighting-up can help prevent hot burns in sensitive areas, especially if incendiary capsules dropped from a helicopter are precisely placed. This is very useful in getting a 'black edge' for rain forest gullies and stream-side vegetation communities, but one has to calculate precisely. The same technique is often used in remote areas for 'steering' fires.

7. Informing the public. Neighbours should be advised, and the burn prepublicised through media such as local papers and on radio so that people are not alarmed when it occurs.

8. Arrangements to suppress fire. There have to be enough suitable persons and equipment on stand-by in case the weather changes without warning. Helicopters that can do water bucketing may be needed. They can help crews to hold the more difficult fire lines.

9. Forward control arrangements. A command structure and an agreed system of communications among all parties need to be in place. So too do arrangements for rescue or evacuation of persons who are injured or in danger ...

10. Helicopter planning. Aerial incendiary work needs to be precisely managed, with the navigator and bombardier operating as a highly planned and organised team. Incendiary capsules must be placed at intervals to minimise adverse fire behaviour.

11. Positioning crews. Fire control crews need to be in position to make sure fires do not get beyond control lines.

12. Surveillance. Some crews need to be on standby to patrol the fire overnight. The next day helicopters will be needed to survey the burn, and perhaps water-bomb flames that persist. Managers must make sure the burn is successful, safe and complete.

(Worboys, Lockwood \& De Lacy, 2001, p.261). 


\section{YYF/Dhimurru Workshops Dhalinbuy (1995) and Wathawuy (1996): Each a Unique Event Expressing Moral Relations Generating Fire as Particular Objects of Governance.}

Each of these short text alerts us that an agreement on distributions associated with firing has been made in the epistemic collectives involved in knowing worrk and prescribed burns respectively. As events, a form of implicit social contract, a memorandum of understanding, is expressed in collective acts of land management firing. And importantly land-management fire as collective act of Yolnu land owning clans, and the collective of professional environmental scientists, speak of different sorts of distributions effected in alternative ways. As moral relations effecting distribution, 'prescribed burn' distributes risk in looking forward, whereas 'worrk' re-effectuates the (past) Ancestral distribution of places as peopled, in looking backwards. The extents to which these collectively imagined (disparate) idealised fires are achieved, are intensive properties of any particular planned land management fire which necessarily eventuates as a particular fire in an episode of firing. In the paper describing the Dhalinbuy workshop firing I described how judgment of the extent of the intensive property we might call 'proper fire-ness,' was made explicit by members of both groups of experts. Recognising this retrospectively, as I do here, raises a possibility, missed at the time, of treating future workshops as a politics of dissensus.

I propose future workshops be understood as explicitly enacting an ethics of dissensus in the here and now of the workshop. In any particular engagement firing event those disparate 'contracts', respectively looking backwards and looking forwards, distributing ownership and risk differentially, must be honored in a firing pursued together in good faith. There is a strong sense in which the fire itself must be recognised as achieving this. This implies we should change how we (groups of humans who wish to manage land through firings) relate to landmanagement fires. No longer can we relate to them as mere physical objects that happen in a nature imagined as 'out-there.' The fires and the humans become the one ontological category - something that will come as no surprise to those who know through Yolnu Aboriginal traditions.

A firing is a doing of a collective here and now, a particular present; it is emergent. Each land management fire whether a worrk, or a prescribed burn, or both (and neither) pursued simultaneously is a singular, unique, active event of governance. We might think of ourselves as relating to the land management fire as like the ball in Serres' (1995) observed game of children's football.

Look at those children out there playing ball. The clumsy ones are playing with the ball as if it were an object, while the more skillful ones handle it as if the ball were playing with them: they move and change position according to how the ball moves and bounces. ... The ball is creating the relationships between [the children]. It ...creates their team, knows itself and represents itself. Yes the ball is active. It is the ball that is playing with the children (Italics added, p.47).

The land management fires play lands and their interested stakeholders and land management practitioners as the ball plays the children. This is so irrespective of whether it is known as a Yolnu Aboriginal worrk or a scientific prescribed burn. But Aboriginal and scientific 'teams' play quite different 'fire-games'. Worrk and prescribed burn are games with quite different rules as indicated by the texts I reproduce in the boxes. And when Aboriginal land managers and scientific land managers come together in episodes of encounter and engagement, we have differing "fire-game teams" being played by the one fire. Teams of practitioners getting irritated with each other as teams repeatedly interact with the fire with incomprehensible moves and routines - seemingly messing up the game. In engagement, the difficult task is 
to learn to negotiate such singular events together; to learn enough of 'the other game' to allow each game to be played well enough, all the while taking care to do difference along with that strategic connection. In such a situation each engagement must be treated on its own terms, recognising that as a single event it is styled as differing distribution of collective moral precepts, in expressing an ethics of dissensus. What governance is is emergent. Every collective act of governance engagement is singular, its own moral passage. This is the principle that informs GroundUP practice.

\section{References}

Foucault, M. (2007). Why study governmentality? In M Senellart (Ed.), \& G. Burchell (trans.), Security, territory, population: lectures at the College de France 1977-1978. Fifth lecture of the annual lecture series given by Michel Foucault in 1977-1978, Paris, France: Palgrave Macmillan.

Serres, M. (1995). Angels. A Modern Myth. Paris \& New York: Flammarion.

Smith, D., Bauman, T., \& Quiggin, R. (2014). Indigenous Governance Development Forum: Mapping Current and Future Research and Resource Needs. Background Paper, Australian Institute of Aboriginal \& Torres Strait Islander Studies (AIATSIS) and Australian Indigenous Governance Institute, 29-30 July in Canberra, p.15. Retrieved from http://www.aigi.com.au/wp-content/ uploads/2014/10/Indigenous-Governance-Forum-Background-Paper.pdf

Verran, H. (2002a). A Postcolonial Moment in Science Studies: Alternative Firing Regimes of Environmental Scientists and Aboriginal Landowners [Special Issue]. Social Studies of Science, 32, 1-33. Retrieved from http://sss.sagepub.com/content/32/5-6/729.full.pdf+html

Verran, H. (2002b). Transferring Strategies of Land Management: Indigenous Land Owners and Environmental Scientists. In M. de Laet (Ed.), Research in Science and Technology Studies, Knowledge and Society (pp.155-181). Oxford: Elsevier \& JAI Press

Verran, H. (2013). Engagements between disparate knowledge traditions: Toward doing difference generatively and in good faith. In L. Green (Ed.), Contested Ecologies, (pp. 141-161). South Africa: Human Sciences Research Council (HSRC) Press.

Worboys, G., Lockwood, M., \& De Lacy, T. (2001). Protected Area Management: Principles and Practice. Oxford: Oxford University Press. 